\title{
Physicochemical condition of two nursery ponds at Iswarganj, Mymensingh
}

\author{
M. Kabil Hossain ${ }^{1}$, M. D. Hossain ${ }^{2}$ M. Habibur Rahman ${ }^{3}$, R. Afza ${ }^{1}$ and D. A. Khanom ${ }^{2}$ \\ ${ }^{1}$ Institute of Biological Sciences, Rajshahi University, ${ }^{2}$ Department of Fisheries, Rajshahi University, , Department of Zoology, \\ Rajshahi University, Rajshahi, Bangladesh.
}

\begin{abstract}
The research work was conducted to measure the nursery pond water quality parameters during the period of June 2006 to May 2007 in Mymensingh. The highest value of water temperature, alkalinity, ammonia, free carbon dioxide, DO, $\mathrm{P}^{\mathrm{H}}$ and hardness was $30.2^{0} \mathrm{C}$ (May’07) in pond-1, 174ppm (Feb.'07) in pond-2, 3.5ppm(July’06) in pond-1, 8.5ppm (Dec.'06\&Jan.'07) in pond-1, 9ppm (July;06) in pond-1(also in April in pond-2), 8.4 (June'06) in pond-2 and 175ppm (Sep.'06) in pond-2 respectively. The lowest value of these parameters was $18^{0} \mathrm{C}$ (Jan.'07) in pond-2, 70ppm (Nov.'06) in pond-1, 0.03ppm (Sep.'06) in pond-2, 4ppm (Sep.'06) in pond-2, 5.5ppm (June’06) in pond-1, 6.2 (Oct.'06) in pond-2 and 64ppm (March’07) in pond- 1 . The value of physicochemical parameters of water had more or less significant combined effect on one another.
\end{abstract}

Key words: Physicochemical, nursery pond, fish fry, disease

\section{Introduction}

In fish nurseries parasitic infestation is one of the most important limiting factors for the growth and survival of fry and fingerlings that subsequently influence economic success of aquaculture practices. The exotic carps and Indian major carps cultivation in nurseries contributes significantly to the inland culture fisheries of Bangladesh (Hossain et al., 1993). The parasite community of fish shows considerable variation with the environmental conditions in which fish live. Various physicochemical factors such as water and atmospheric temperature, $\mathrm{p}^{\mathrm{H}}$, hardness of water, dissolved oxygen, biological oxygen demand (BOD) have strong influence on fish health and their resistance to the attack by the causative agents (Welch, 1941; Sneisko, 1974; Plumb et al.,1988; Shresta, 1990). Dogiel (1961) suggested 15 factors, which directly influenced the parasite fauna of fish. These factors include age, diet and abundance of fish, independence of number of parasite fauna within the fish and season. Wisheiwski (1958) stated that the character of water body influences and determines the parasite fauna of its community. If adequate techniques are developed regarding the nursing and rearing of carp hatchlings in controlled conditions, it would definitely pave the way for the fish farmer to adopt fish farming as a lucrative money earning profession so as to ensure the steady availability of cheap good quality fish seed for augmenting commercial fish production. In Bangladesh information on prevalence and extent of damage caused by ectoparasitic diseases in carp nursery operation is scanty. Therefore, it was presumed that the parasite fauna of any particular habitat was determined by a combination of various ecological factors. The present study was designed to investigate the water quality parameters of two nursery ponds at Iswarganj, Mymensingh district in Bangladesh.

\section{Materials and Methods}

Two nursery ponds were selected at Iswarganj, Mymensingh for this research. One pond was 20 decimal in area and 4 feet in depth where other one was 15 decimal in area and 3.5 feet in depth. The water from these two nursery ponds was collected and studied the physicochemical parameters once in a month. The study in this context was conducted from June 2006 to May 2007 at Iswarganj in Mymensingh district. These ponds are used as nursey ponds for 6 months and then fingerlings are left in this popnd for 6 months for growing as market fish. This time water depth was kept upto 6 feet. The woner keeps water all the year round in these ponds.

In order to observe seasonal changes in occurrence of the parasites, infected fishes were collected seasonally. The fishes were caught from the study areas using dip nets and different mesh sized cast nets. Fingerlings were shifted in water filled polyethylene bags containing 3-5 times more air than water. After having removed the fish from the water, the colour of the body was noted (decolouration, darkening, blackening etc.), as well as the presence of any cloudiness of the skin (gray or white), reddening, ragged or torn fins, raised scales, white spots or parasites visible to the naked eye. The skin was always examined with a magnifying glass. Attention was paid to the natural openings and to the skin, in order to detect the presence of areas of trauma, ulcers, abscesses, loss of colour and parasites. Parasites were idenfied following the methods of Kabata, 1985.

Water quality data viz. temperature $\left({ }^{\circ} \mathrm{C}\right), \mathrm{P}^{\mathrm{H}}$, unionized ammonia (ppm) and alkalinity(ppm), dissolved oxygen (ppm), free carbon-dioxide (ppm) and total hardness (ppm) were recorded on the spot during sampling using portable Hach Kit (FF-2). Most samplings of water were done between 7 A.M. to $11 \mathrm{~A}$. $M$. from the surface layer near the shore. Mean \pm SD 
and corelation coeficent were calculated following the method of Mian and Miyan, 1984. All the data from two nursery ponds were recorded accordingly for the convenience of study.

\section{Results and Discussion}

The monthly variations of physicochemical parameters of water of the two sampling ponds recorded during the period of investigations are shown in Table $1 \& 2$. Water temperature showed variations in different months of the year in two nursery ponds. The highest water temperature was $30.2^{0} \mathrm{c}$ in the month of May 2007 in poind -1 (Table 1) and that was $28.5^{\circ} \mathrm{C}$ in the month of June 2006 in pond-2 (Table 2)

Table 1. Monthly variations in physicochemical parameters of nursery pond -1.

\begin{tabular}{|c|c|c|c|c|c|c|c|}
\hline \multirow{2}{*}{$\begin{array}{l}\text { Months } \\
\text { Months }\end{array}$} & \multicolumn{7}{|c|}{ Physicochemical parameters } \\
\hline & $\begin{array}{c}\text { Temperature } \\
\left({ }^{0} \mathrm{c}\right)\end{array}$ & $\begin{array}{c}\text { Alkalinity } \\
\text { (ppm) }\end{array}$ & $\begin{array}{c}\text { Ammonia } \\
\text { (ppm) }\end{array}$ & $\begin{array}{c}\text { Free } \mathrm{CO}_{2} \\
(\mathrm{ppm})\end{array}$ & $\begin{array}{c}\text { DO } \\
(\mathrm{ppm})\end{array}$ & $\mathbf{P}^{\mathrm{H}}$ & $\begin{array}{c}\text { Hardness } \\
(\mathrm{ppm})\end{array}$ \\
\hline June’06 & \begin{tabular}{l|l}
30.0 \\
\end{tabular} & 139 & 2.2 & 4.5 & 5.5 & 7.4 & 150 \\
\hline July’06 & 26.5 & 90 & 3.5 & 6.0 & 9.0 & 7.2 & 70 \\
\hline Aug.'06 & 26.0 & 89 & 2.5 & 6.8 & 7.8 & 8.0 & 70 \\
\hline Sep.’06 & 27.2 & 78 & 2.0 & 7.5 & 7.2 & 7.8 & 65 \\
\hline Oct.'06 & 24.2 & 96 & 1.5 & 9.0 & 8.2 & 7.5 & 80 \\
\hline Nov.’06 & 20.4 & 70 & 1.2 & 7.8 & 7.4 & 6.5 & 75 \\
\hline Dec.'06 & 21.5 & 100 & 0.2 & 8.5 & 6.5 & 6.9 & 80 \\
\hline Jan.'07 & 19.5 & 115 & 1.0 & 8.5 & 6.8 & 7.5 & 100 \\
\hline Feb.’07 & 27.0 & 105 & 0.5 & 7.5 & 8.0 & 8.0 & 90 \\
\hline Mar.’07 & 24.5 & 75 & 2.0 & 8.0 & 7.8 & 7.1 & 64 \\
\hline Apr.’07 & 24.2 & 105 & 1.8 & 8.2 & 8.0 & 7.5 & 100 \\
\hline May’07 & 30.2 & 85 & 2.1 & 7.0 & 8.5 & 7.5 & 65 \\
\hline Mean +SD & $\begin{array}{l}25.1 \\
\pm 3.3\end{array}$ & $\begin{array}{c}94.8 \\
\pm 16.6\end{array}$ & $\begin{array}{c}1.7 \\
\pm 0.8\end{array}$ & $\begin{array}{c}7.4 \\
\pm 1.2\end{array}$ & $\begin{array}{c}7.6 \\
\pm 0.9\end{array}$ & $\begin{array}{c}7.4 \\
\pm 0.4\end{array}$ & $\begin{array}{c}84.1 \\
\pm 23.3\end{array}$ \\
\hline $\begin{array}{l}\text { *Suitable for } \\
\text { fish }\end{array}$ & $25-31$ & $40-200$ & $\begin{array}{c}\text { Bellow } \\
0.025\end{array}$ & Bellow 12 & $5-7$ & $6.5-9$ & $40-200$ \\
\hline $\begin{array}{l}\text { *Harmful for } \\
\text { fish }\end{array}$ & $\begin{array}{l}\text { Bellow } 14 \text { and } \\
\text { above } 39.5\end{array}$ & $\begin{array}{c}\text { Bellow } 15 \text { and } \\
\text { above } 300\end{array}$ & Above 0.025 & Above 12 & Bellow 1.0 & $\begin{array}{c}\text { Bellow } 4 \text { and } \\
\text { above } 11\end{array}$ & $\begin{array}{c}\text { Bellow } 15 \text { and } \\
\text { above } 300\end{array}$ \\
\hline
\end{tabular}

*Jhingran,1988

Table 2. Monthly variations in physicochemical parameters of nursery pond -2 .

\begin{tabular}{|c|c|c|c|c|c|c|c|}
\hline \multirow{2}{*}{$\begin{array}{l}\text { Months } \\
\text { Months }\end{array}$} & \multicolumn{7}{|c|}{ Physicochemical parameters } \\
\hline & $\begin{array}{c}\text { Temperature } \\
\left({ }^{0} \mathrm{c}\right)\end{array}$ & $\begin{array}{c}\begin{array}{c}\text { Alkalinity } \\
(\mathrm{ppm})\end{array} \\
\end{array}$ & $\begin{array}{c}\text { Ammonia } \\
\text { (ppm) }\end{array}$ & $\begin{array}{c}\text { Free } \mathrm{CO}_{2} \\
(\mathrm{ppm})\end{array}$ & $\begin{array}{c}\text { DO } \\
(\mathrm{ppm})\end{array}$ & $\mathbf{P}^{\mathbf{H}}$ & $\begin{array}{c}\text { Hardness } \\
(\mathrm{ppm})\end{array}$ \\
\hline June’06 & 28.5 & 100 & 3.0 & 5.6 & 7.0 & 8.4 & 82 \\
\hline July’06 & 27.0 & 95 & 1.4 & 6.0 & 7.9 & 7.8 & 65 \\
\hline Aug.'06 & 25.5 & 110 & 0.9 & 4.5 & 6.7 & 8.0 & 95 \\
\hline Sep.’06 & 27.2 & 85 & 0.03 & 4.0 & 8.0 & 7.5 & 175 \\
\hline Oct.’06 & 25.0 & 95 & 0.24 & 4.5 & 8.2 & 6.2 & 167 \\
\hline Nov.'06 & 21.0 & 105 & 3.2 & 5.0 & 6.0 & 8.0 & 120 \\
\hline Dec.'06 & 20.5 & 135 & 2.5 & 7.5 & 8.0 & 8.1 & 105 \\
\hline Jan.'07 & 18.0 & 160 & 3.0 & 7.2 & 8.0 & 7.5 & 140 \\
\hline Feb.’07 & 19.2 & 174 & 3.0 & 7.0 & 8.5 & 8.2 & 140 \\
\hline Mar.'07 & 22.5 & 170 & 3.0 & 6.5 & 8.2 & 7.8 & 150 \\
\hline Apr.’07 & 23.5 & 140 & 3.0 & 6.0 & 9.0 & 7.5 & 100 \\
\hline May’07 & 25.2 & 115 & 2.8 & 8.2 & 6.5 & 8.0 & 85 \\
\hline Mean +SD & $\begin{array}{r}23.6 \\
\pm 3.2 \\
\end{array}$ & $\begin{array}{l}123.7 \\
\pm 29.8 \\
\end{array}$ & $\begin{array}{c}2.2 \\
\pm 1.1 \\
\end{array}$ & $\begin{array}{c}6.0 \\
\pm 1.3 \\
\end{array}$ & $\begin{array}{c}7.67 \\
\pm 0.86 \\
\end{array}$ & $\begin{array}{c}7.75 \\
\pm 0.54 \\
\end{array}$ & $\begin{array}{c}117 \\
\pm 35.5 \\
\end{array}$ \\
\hline $\begin{array}{l}* \text { Suitable } \\
\text { for fish }\end{array}$ & $25-31$ & $40-200$ & $\begin{array}{c}\text { Bellow } \\
0.025\end{array}$ & Bellow 12 & $5-7$ & $6.5-9$ & $40-200$ \\
\hline $\begin{array}{l}* \text { Harmful } \\
\text { for fish }\end{array}$ & $\begin{array}{c}\text { Bellow } 14 \text { and } \\
\text { above } 39.5\end{array}$ & $\begin{array}{c}\text { Bellow } 15 \text { and } \\
\text { above } 300\end{array}$ & Above 0.025 & Above 12 & Bellow 1.0 & $\begin{array}{c}\text { Bellow } 4 \text { and } \\
\text { above } 11\end{array}$ & $\begin{array}{c}\text { Bellow } 15 \text { and } \\
\text { above } 300\end{array}$ \\
\hline
\end{tabular}


The lowest water temperature was $19.5^{\circ} \mathrm{C}$ in the month of January 2007 in pond- 1 and that was $18.0^{\circ} \mathrm{C}$ in the same month in pond-2. The presence of bicarbonate in water was responsible for the presence of alkalinity. The alkalinity of water observed was minimum (70ppm) in November 2006 and maximum (139ppm) in June 2006 in the pond-1. In pond-2 the value of total alkalinity of water was found fluctuated from the minimum of 85ppm in September 2006 to the maximum of 174ppm in February 2007. The ammonia of water was observed to be minimum in December 2006 (0.2ppm), September 2006 (0.03ppm) and maximum was in the month of July 2006 (3.5ppm) and November 2006 (3.2ppm) in the pond-1 and pond-2 respectively (Table $1 \& 2$ respectively). The maximum carbon dioxide recorded were 8.5ppm (December `06 \& January `07), 8.2ppm (May `07) and the minimum were 4.5ppm(June 06) and 4.0ppm (September `06) in the pond- 1 and pond-2 respectively (Table 1\&2 respectively). In pond-1, the highest and lowest concentrations of DO of water were $9.0 \mathrm{ppm}$ and 5.5ppm in the month of July 2006 and June 2006 respectively. The highest and lowest DO concentrations of pond-2 were $9.0 \mathrm{ppm}$ and $6.0 \mathrm{ppm}$ in the month of April 2007 and November 2006 respectively. The average $\mathrm{P}^{\mathrm{H}}$ value of water of the pond- 1 was found to be varied from a minimum of 6.5 (November '06) to a maximum of 8.0 (August '06 and February '07) and that of pond-2 was found to be varied from a minimum of 6.2 (October'06) to maximum of 8.4 (June '06). The highest and lowest values of hardness were in the month of June 2006 (150ppm), September 2006 (175ppm) and March 2007 (64 ppm), July 2006 (65 ppm) in the pond- 1 and pond- 2 respectively (Table $1 \& 2$ respectively). In pond-1, number of 540 fishe were observed. of them $36.66 \%$ fishes were infested by protozoan parasites and $33.33 \%$ by monognean parasites. In pond-2, number of 460 fishe were observed. of them $34.78 \%$ fishes were infested by protozoan parasites and $30.22 \%$ by monognean parasites (Table 5).

The monthly record of water quality parametres showed fluctuations in different months between the two ponds. The variations of values of different parameters are supposed due to the difference of water depth, soil quality, water polution, turbidity, management system, fingerling stocking density. Our finding is supported by the finding of Khalf \& MacDonald (1975). A close relationship between $\mathrm{P}^{\mathrm{H}}$ and carbonate content of water was observed. When they fluctuate the relationship become hampered or fluctuated. As a result the optimum range of these parameters for fish living is also fluctuated and so the favourable environment for fish lives deteriorates and fish suffer more Table 1\&2). These cause the fish susceptible to parasites and are affected by them. The parasites cause diseases to fishes. The fingerlings are more susceptible to diseases. As a result they die rapidly. Rahman et.al. (1975), Murty et al. (1978) also observed similar results in the treated ponds. Corelation between temperature and DO showed negatively corelation and of other variables are shown in Table 3. The total alkalinity showed more or less direct relationships with $\mathrm{P}^{\mathrm{H}}$ and $\mathrm{CO}_{2}$ (Tabl 4). More or less inverse relationship was found between $\mathrm{DO}$ and $\mathrm{Co}_{2}$, which also was observed by Ali et al. (1982). Chawdhury et al. (1978) reported $\mathrm{Co}_{2}$ fluctuating range between nil and $3.8 \mathrm{ppm}$. $\mathrm{P}^{\mathrm{H}}$ showed more or less inverse relationship with $\mathrm{Co}_{2}$ (Table 4). Such observation was supported by Michael (1969). At $\mathrm{P}^{\mathrm{H}} 4$ and at 11 gills, lens and cornea of fish eyes are destroyed, stop feeding and fish die. Water temperature bellow $14^{\circ} \mathrm{C}$ and above $39.50^{\circ} \mathrm{C}$ is fatal for fish. The amount of unionized Ammonia $\left(\mathrm{NH}_{3}\right)$ should not be more than $0.025 \mathrm{mg} / \mathrm{L}$. Fish cannot take $\mathrm{O}_{2}$ if carbon dioxide remains high in water. $\mathrm{O}_{2}$ transportation of blood decreases. As a result fish suffer from suffocation and die. Free $\mathrm{Co}_{2}$ at a concentration of more than $15 \mathrm{ppm}$ is detrimental to pond fishes. The air breathing fishes can survive at $\mathrm{Co}_{2} 100 \mathrm{ppm}$. So there was a relationship of fish disease with the value of water quality parameters. The water quality has relationship with the one another. In case of low aquatic environmental temperature fish reduces metabolic activity that in term makes the fish more susceptible during the winter period towards parasititc infection. Low Alkalinity reduces the buffer capacity of water and badly affects the pond ecosystem that in turn cause stress to the fish and become more susceptible. Fish cannot take $\mathrm{O}_{2}$ if carbon dioxide remains high in water. $\mathrm{O}_{2}$ transportation of blood decreases. As a result fish suffer from suffocation and die. So there was a relationship of fish disease with the value of water quality parameters. The water quality parameters fluctuate mainly in winter and in sometimes in summer. On the other hands fish become affected with diseases in these season. Fishes were infested more by protozoan parasites than by monogenean (Table 5). Measure should be taken to control the water level fluctuation, aquatic vegetation, organic debris and water pollution. Checking of water quality, prevention of algal bloom and control of $\mathrm{O}_{2}$ depletion should be maintained as well. The out standing results of such type of study will provide clue to further studies in different aspects of the water quality parameters as well as parasites of freshwater fish, which will be of much helpful for the development of fish nursery and ultimately will contribute to the production of fishes for the nation. 
Table 3. Correlation \& test of significance of water quality variables of the two ponds.

\begin{tabular}{l|c|c|c|c}
\hline \multirow{2}{*}{ Correlation between } & \multicolumn{2}{|c|}{ Pond-1 } & \multicolumn{2}{c}{ Pond-2 } \\
\cline { 2 - 5 } & Value of "r" & Remarks & Value of "r" & Remarks \\
\hline Temp.\& DO & -0.562403916 & Negatively correlated & -0.529106716 & Negatively correlated \\
\hline Temp.\& Ammonia & 0.884390548 & Positively correlated & 0.765716931 & Positively correlated \\
\hline $\mathrm{P}^{\mathrm{H}}$ and Alkalinity & -0.959364413 & Negatively correlated & -0.390877575 & Negatively correlated \\
\hline $\mathrm{P}^{\mathrm{H}}$ and $\mathrm{CO}_{2}$ & -0.882497503 & Negatively correlated & -0.269565067 & Negatively correlated \\
\hline
\end{tabular}

Table 4. Relationship found between the water quality variables.

\begin{tabular}{l|l|l|l}
\hline Parameters & Relation & Parameters & Relation \\
\hline Temperature \& Oxygen & Inverse & $\mathrm{O}_{2} \& p^{\mathrm{H}}$ & Parallel \\
\hline Temperature and Ammonia & Parallel & Alkalinity \& $p^{\mathrm{H}}$ & Inverse \\
\hline $\mathrm{Co}_{2}$ \& Oxygen & Inverse & $\mathrm{Co}_{2} \& p^{\mathrm{H}}$ & Inverse \\
\hline
\end{tabular}

Table 5. Total number of observed fish and \% of infested fish in the two ponds.

\begin{tabular}{l|l|l|c|c}
\hline Study areas & Number of fish observed & \multicolumn{2}{|c|}{ Number of fish infested by } & Infestation \\
\hline \multirow{3}{*}{ Pond-1 } & \multirow{2}{*}{540} & Protoan parasites & 198 & $36.66 \%$ \\
\cline { 2 - 5 } Pond-2 & \multirow{2}{*}{460} & Monogenean parasites & 180 & $33.33 \%$ \\
\cline { 2 - 5 } & & Mrotoan parasites & 160 & $34.78 \%$ \\
\hline
\end{tabular}

\section{References}

Ali, M .H, Akber, M.A. \& Rahman, M. H. 1982. Utilization of fish ponds in Mymensing district. Bangladesh J.Agri.res. 5:1-2:103-104.

Chawdhury,H, Rao, V.G.S, Shaha, G.N.Rount, M. \& Ranaujia, D.R. 1978. Record fish production through intensive fish culture in a farmer's ponds. J.Inland Fish Soc. India. 10:19-97.

Dogiel, V.A, 1961. Ecology of the parasites of fresh water fish in parasitology of fishes. Oliver and Bayd, London. pp 1-47.

Hossain, M. A., A. N. H. Banu \& M. A. Khan, 1993. Investigation into the occurrence of parasites in carps, catfish and tilapia from Mymensingh. Progress. Agric., 4(1\&2): 11-16.

Jhingran, V.G., 1988. Fish and fishes of India. Hindustan Publishing Corporation (India), Delhi.

Kabata Z., 1985. Parasites and Diseases of Fish Cultured in the Tropics. Taylor and Francis, London and Philadelphia

Khalaf, A. N. \& Mac Donald, L. J., 1975. Physico-chemical conditions in temporary ponds in the New Forest. Hydrobiol. 47(2): 301-318.

Mian, M.A. \& Miyan, M.A., 1984. An Introduction to Statistics. Ideal Library, Dhaka, Bangladesh. 345-352.

Michael, G.R. 1969. Seasonal trends on physicochemical factors and plankton of fresh water fish pond and their role in fish culture. Hydrobiology.
Murty, D.S, Saha, G.N., Seevaraj, C, Reddy, P.V.G.K. \& Dey, R.K. 1978. Studies on increased fish production in composite fish culture through nitrogenous fertilization, with and without supplementary feeding. J. Inland Fish Soc.India. 10: 39-45.

Plumb,J.A., Grizzle J.M. \& Figueiredo.1988. Necrosis and bacterial infection in channel catfish Ictalarus punctatus following hypoxia. J.Wildl. Dis.12: 247-253.

Rahman, K. Ghosh, S. R. \& Chatterjee, D. K. 1975. Studies on the ecology of fishponds with special reference to bottom fauna. J. Inland fish. Soc. India. 7: 173-181.

Shresta, G.B. 1990.Status of Epizootic Ulcerative Diseases Syndrome (EUDS) in Nepal. In regional research program on relationship between EUS in fish and environment. 13-16 August, 1990. NACA, Bangkok, Nepal Report pp 35-38.

Sneisko, S.F.1974. The effect of environmental stress on out break of infectious diseases of fishes. J. Fish. Biol. 6: 197-208.

Welch, P. S. 1941. Dissolved oxygen in relation to lake types in a symposium on Hydrobiol. Univ. Wis. Press.

Wisheiwski, W. L. 1958. Characterization of the parasite fauna of an Eutrophic lake. Actoparasitol. Pol. 6, pp. 1-64.

Manuscript received on 28.05.2008, accepted on 223.09.2008 